\title{
The Gray Relevance Analysis about the Affecting Factors of China's Demand for Money
}

\author{
Ronghua Chen ${ }^{1,2}$ \\ 1 Hohai University, Nanjing, China; \\ 2 Jianghai Polytechnic College, Yangzhou, China \\ crh321@hotmail.com;gong197509@163.com
}

\begin{abstract}
GDP, interest rate, price level and stock market are the main factors affecting monetary demand in China. In this paper, the gray relevance analysis is used to analyze the relevance degree between monetary demand and its main affecting factors. The result shows that the affecting factors from strong to weak are GDP, price level, interest rate and stock market. Finally, on the basis of the conclusions of the analysis, some tentative policy recommendations are proposed.
\end{abstract}

Keywords- monetary demand; gray relevance analysis; stock market; price level

\section{I .INTRODUCTION}

Theory research about monetary demand has a long history and many economists have made some theoretical analysis, in which there are three influential theories: traditional quantity theory of monetary demand, Keynesian theory about monetary demand and Friedman's modern quantity theory of monetary demand. Under the reform and economic transition, from the late 1980s on, China's scholars have been learning from western economic theory and studying monetary demand in China.

Although China's scholars have done a lot of empirical research about monetary demand of China, but none on the study the relevance degree between monetary demand and its main affecting factors. In view of this, an empirical analysis is made in this paper to analyze the relevance degree between monetary demand and its main influencing factors in this paper.

\section{THE ANALYSIS ABOUT THE AFFECTING FACTORS OF CHINA'S MONETARY DEMAND}

\section{A. Variable Selection}

In China's scholars' empirical studies, which are generally based on western economic theories, the factors affecting monetary demand are thought to have two kinds of variables: the scale variable and opportunity cost variable. This paper uses the following model (Changmao Zhao, 2002): $M=f(P, Y, R, Z)$, where $M$ is the demand for money; $\mathrm{P}$ is the general price level; $\mathrm{Y}$ represents the scale variable; $\mathrm{R}$ represents the opportunity cost variable, and $\mathrm{Z}$ represents other variables.

With the development of China's stock market, the impact of stock market on monetary demand causes people's research. In general, the impact of stock market on monetary demand reflects itself in three aspects (Yupeng Li,
2008). First, the wealth effect: the rise of stock prices means that people's wealth and income increase, and corresponding monetary demand increases; Second, the trading effect: with stock as a financial commodity, its trading need money as a vehicle. The more the trading quantity, the more the demand for money is. Third, the substitution effect, the increase of stock value makes people adjust their asset structure, holding more stocks and less money.

According to existing research results, the main factors that influence China's demand for money are price level, the scale variable, the opportunity cost variable and stock market. This paper selects broad money balances $\mathrm{M}_{2}$ to represent the demand for money, the retail price index $\mathrm{P}$ to represent the general price level, GDP to represent the scale variable, the one-year deposit interest rate $\mathrm{R}$ to represent the opportunity cost variable and China's stock value in circulation to represent the stock market value SV.

Taking into account data availability, this paper selects the time series data from the year 1993 to 2010 for empirical analysis.

\section{B. The Steps of Gray Relevance Analysis}

Gray relevance analysis is to analyze the relevance degree among various sequences. Its basic idea is to determine the relevance degree according to the proximity of sequence geometry. The closer the curves, the relevance degree between the sequences is higher. The steps are as follows:

Step one: to determine the reference series $\mathrm{Y}(\mathrm{t})\left(\mathrm{M}_{2}\right)$ and the comparative sequence $\mathrm{X}_{\mathrm{i}}(\mathrm{t})(\mathrm{GDP}, \mathrm{R}, \mathrm{P}, \mathrm{SV})$.

Step two: to process variables for dimensionless. Because different variables have different units, and cannot compare, so dimensionless data processing is done before the gray relevance analysis.

In this paper, dimensionless data processing is as follows: $\mathrm{Y}^{\prime}(\mathrm{t})=\mathrm{Y}(\mathrm{t}) / \mathrm{Y}(1)$ and $\mathrm{X}^{\prime}{ }_{\mathrm{i}}(\mathrm{t})=\mathrm{X}_{\mathrm{i}}(\mathrm{t}) / \mathrm{X}_{\mathrm{i}}(1)$.

Step three: to calculate the difference of corresponding series. That is $\triangle_{\mathrm{i}}(\mathrm{t})=\left|\mathrm{Y}^{\prime}(\mathrm{t})-\mathrm{X}^{\prime}{ }_{\mathrm{i}}(\mathrm{t})\right|, \triangle \max$ and $\triangle$ min are the maximum and minimum of $\triangle_{\mathrm{i}}(\mathrm{t})$ respectively.

Step four: to calculate the relevance coefficient $\xi_{i}(t)$.

$\xi_{\mathrm{i}}(\mathrm{t})=(\triangle \min +\rho \triangle \max ) /\left(\triangle_{\mathrm{i}}(\mathrm{t})+\rho \triangle \max \right) . \rho$ is called the resolution factor, $0 \leqslant \rho \leqslant 1$. The introduction of $\rho$ is to reduce the impact of extreme values. 
Step five: to calculate the relevance degree $\mathrm{r}_{\mathrm{i}}=\frac{1}{n} \sum \xi$

i(t)

C. Empirical Results

Based on the above calculation steps, we can obtain $\triangle \min =0$ and $\triangle \max =158.094$.In order to improve the significant differences between relevance coefficients, this paper takes $\rho=0.025$ to calculate the relevance coefficient $\xi_{\mathrm{i}}(\mathrm{t})$. We can get the relevance coefficient table, as shown in table 1.

Table 1: the gray relevance coefficient of factors that influence China's monetary demand

\begin{tabular}{|c|c|c|c|c|}
\hline year & $\xi_{1}(t)$ & $\xi_{2}(t)$ & $\xi_{3}(t)$ & $\xi_{4}(t)$ \\
\hline $\begin{array}{ll} & 199 \\
3 & \\
\end{array}$ & 1 & 1 & 1 & 1 \\
\hline $\begin{array}{ll} & 199 \\
4 & \\
\end{array}$ & 0.995 & 0.937 & 0.969 & 0.947 \\
\hline \begin{tabular}{|ll} 
& 199 \\
5 & \\
\end{tabular} & 0.995 & 0.858 & 0.920 & 0.858 \\
\hline $\begin{array}{ll} & 199 \\
6 & \\
\end{array}$ & 0.959 & 0.745 & 0.850 & 0.776 \\
\hline $\begin{array}{ll} & 199 \\
7 & \\
\end{array}$ & 0.914 & 0.659 & 0.780 & 0.536 \\
\hline $\begin{array}{ll} & 199 \\
8 & \\
\end{array}$ & 0.867 & 0.609 & 0.719 & 0.518 \\
\hline $\begin{array}{ll} & 199 \\
9 & \end{array}$ & 0.815 & 0.551 & 0.661 & 0.393 \\
\hline $\begin{array}{ll} & 200 \\
0 & \end{array}$ & 0.790 & 0.521 & 0.615 & 0.211 \\
\hline $\begin{array}{ll} & 200 \\
1 & \end{array}$ & 0.734 & 0.478 & 0.556 & 0.244 \\
\hline $\begin{array}{ll} & 200 \\
2 & \\
\end{array}$ & 0.676 & 0.436 & 0.501 & 0.301 \\
\hline $\begin{array}{ll} & 200 \\
3 & \\
\end{array}$ & 0.613 & 0.391 & 0.442 & 0.306 \\
\hline 200 & 0.589 & 0.359 & 0.402 & 0.386 \\
\hline $5 \quad 200$ & 0.539 & 0.321 & 0.356 & 0.512 \\
\hline $\begin{array}{ll} & 200 \\
6\end{array}$ & 0.503 & 0.290 & 0.318 & 0.171 \\
\hline $\begin{array}{ll} & 200 \\
7 & \end{array}$ & 0.467 & 0.260 & 0.281 & 0.039 \\
\hline $\begin{array}{ll} & 200 \\
8 & \\
\end{array}$ & 0.436 & 0.229 & 0.247 & 0.092 \\
\hline $9 \quad 200$ & 0.334 & 0.187 & 0.200 & 0.024 \\
\hline $\begin{array}{ll} & 201 \\
0 & \\
\end{array}$ & 0.305 & 0.126 & 0.154 & 0.067 \\
\hline
\end{tabular}

$\left(\xi_{1}, \xi_{2}, \xi_{3}, \xi_{4}\right.$ represent the gray relevance coefficient of GDP, interest rate, price level, stock market respectively)

Calculating the arithmetic average of the gray relevance coefficient, we can get the relevance degree of every factor: $r_{1}=0.696, r_{2}=0.498, r_{3}=0.554, r_{4}=0.410$.

The result of the relevance degree shows that the factors of affecting China's monetary demand from strong to weak are GDP, price level, interest rate and stock market. This suggests that the most important factors that affect China's monetary demand are GDP and price level, and interest rate and stock market are in a secondary position.

\section{CONCLUSIONS AND RECOMMENDATIONS}

\section{A. Conclusions}

Money as a general equivalent, its essential function is to perform the function of circulation. The quantity of commodity circulation determines the quantity of money in circulation. So GDP is the most fundamental factor that determines the monetary demand, which is consistent with the empirical results of the present study.

Of the factors that affect China's monetary demand, the role of price level $\mathrm{P}$ is relatively important, which means that inflation and deflation will have a major impact on the demand for money. Therefore, in order to maintain the stability of monetary demand, it is critical to maintain the relative stability of the general price level.

In western economic theory, interest rate is one of the most important factors that affect the demand for money. But in China, the role of interest rate is not particularly important. Possible explanation is that China's current interest rate mechanism is not perfect and that China's interest rate is not market-oriented, with its interest rate determined by the central bank. So the changes of interest rate are not the result of supply and demand of money, and interest rate does not have a substantial impact on speculative demand for money. However, with the maturity of China's financial markets, the role of interest rate on monetary demand will increase.

Based on the empirical results, the impact of stock market on the demand for money is minimal in the four factors. This is also consistent with China's reality. At present, the wealth effect and the substitution effect of China' stock market is not significant. China's stock market is not yet mature, and most people that invest in stock market fail to achieve profit from their investment, and the wealth effect does not show. In addition, China's stock market is very unstable, and after several ups and downs, people fear the high risk of stock market. So most people only invest a small amount of money in stock market, and the substitution effect is not obvious. The trading effect is closely related with the performance of stock market. But the performance of China's stock market is poor, so the trading effect is not obvious too. All in all, stock market is a factor that affects the demand for money, but in China, it is not important factor.

\section{B Recommendations}

1) To promote market-oriented reform of interest rate. 
At present, China takes the supply of money as an intermediate target of monetary policy. This is not ideal, because income and prices have a significant effect on the demand for money, and income and prices are not easy to keep stable. So China should promote market-oriented reform of interest rate, and let interest rate reflect the supply and demand of money. At that time, interest rate, as an intermediate target of monetary policy, can improve the effectiveness of monetary policy.

2) To stabilize price level

Price volatility may lead to instability in money demand, thereby affecting monetary policy of the central bank, and increases the difficulty of money supply. So relative price stability is necessary and the government should guard against price volatility.

\section{REFERENCES}

[1] Shengfang Wang, Xuewei Wang. "The analysis of factors affecting Chinese monetary demand and policy implications”. Shanghai Economic Research, 2009(2) pp 44-50

[2] Yupeng Li, Wenliu Zai, Yanxia Zhao. "The empirical research of the impact on the stock market to monetary demand.” China Market, 2008(13)

[3]Changmao Zhao. Modern Financial Theory. China Financial and Economic Press, 2002

[4]Dong Du, Qinghua Pang, Yan Wu. Modern Comprehensive Evaluation Methods and Case Selection. Qinghua University Press, 2008

[5]Zhao Wei, "The four factors that affect the demand for money". Statistics and Decision, 2009(1) pp 129-130

[6]Xuefeng Zhang, "The empirical analysis of the demand for money in China”. Application of statistics and management, 2009(1) pp 111-116 